\title{
The Management Strategy of Cultural Tourism: A Case Study of Sakon Nakhon Province, Thailand
}

\author{
Winita Panich ${ }^{1}$, Thirachaya Maneenetr ${ }^{1}$, Taksina Kunarucks ${ }^{2} \&$ Thongphon Promsaka Na Sakolnakorn ${ }^{3}$ \\ ${ }^{1}$ Faculty of Management Science, Khon Kaen University, Thailand \\ ${ }^{2}$ Faculty of Humanities, Chiang Mai University, Thailand \\ ${ }^{3}$ Institute for Peace Studies, Prince of Songkla University, Hat Yai Campus, Thailand \\ Correspondence: Winita Panich, Faculty of Management Science, Khon Kaen University, Khon Kaen 40002, \\ Thailand. E-mail: greenworldtrvl.m@gmail.com
}

Received: April 16, 2014 Accepted: June 4, 2014 Online Published: July 11, 2014

doi:10.5539/ass.v10n15p48 URL: http://dx.doi.org/10.5539/ass.v10n15p48

\begin{abstract}
The objectives of this study are to examine the motivation of tourists who came to visit Sakon Nakhon province and to study the guidelines of management strategy for cultural tourism in Sakon Nakhon province. In this paper, we used quantitative and qualitative methods by providing 800 questionnaires to Thais and foreign travelers, and we analyzed data using mean and standard deviation. In addition, we also used a focus group by inviting 20 experts involved in the tourism industry to discuss strategic management and analyzed the data using content and descriptive analysis. The results of this study show that Sakon Nakhon has several attractive places to motivate tourists to visit. The researchers recommend four strategic guidelines and eighteen management objectives to develop cultural tourism, and we also suggest three policy implementations for tourism development.
\end{abstract}

Keywords: management strategy, cultural tourism, Sakon Nakhon province, Thailand

\section{Introduction}

Cultural tourism is the subset of tourism concerned with a country or region's culture; specifically, the lifestyle of the people in those geographical areas, the history of those people, their art, architecture, religions, and other elements that help shape their way of life. Cultural tourism includes tourism in urban areas, particularly historic or large cities and their cultural facilities such as museums and theaters (Mohammed, 2013). Cultural tourism comprises all aspects of travel, whereby travelers learn about the history and heritage of others or about their contemporary ways of life or thought (McIntosh \& Goeldner, 1994). Tourism can bring significant income into the area (Kantawateera et. al, 2014). Tourism and culture are related to tourism activities such as bringing people to visit and learn about a different way of life, different culture, and backgrounds (Wei, 2012).

Sakon Nakhon province is in the upper northeast. It is in the Phu Phan mountain range and has many forest temple retreats for meditation. Sakon Nakhon is 647 kilometers from Bangkok and has an area of 9,605 square kilometers (Wikitravel, 2014). Sakon Nakhon has many tourism attractions such as festivals like the So Ram Luk Festival, held to commemorate the So ethnic group. It is held annually on the 4th waxing moon of March in the Kusumal district. Other tourist attractions include the Phu Thai Ethnic group at None Hom village, the Phu Phan Rajanivet Palace, the Sakon Nakhon Cultural Center,, Nam Oun Dam, Wha Yai, and Ban Don Daeng weaving village, and the Phu Phan mountain range.

In 2011, 449,337 Thai tourists visited Sakon Nakhon, Approximately 2,532 foreign tourists visited Sakon Nakhon. Thai tourists spent about \$25 USD/day and foreigners about $\$ 40$ USD/day. Revenue from Thai tourists in 2011was \$30 Million USD, and from foreigners approximately \$300,000 USD (National Statistical Office of Thailand, 2011). However, Sakon Nakhon province still faces problems in its infrastructure such as water supply, electrical systems in rural areas, natural resource protection, and criminal activity in cities (Sakon Nakhon Provincial, 2013). The problems of Sakon Nakhon province are related to tourism. Now all stakeholders related to tourism in Sakon Nakhon are collaborating to develop tourism and solving problems to increase the number of tourists and revenue to the province and improve economic growth. This research is important to be used as a guideline to develop cultural tourism. Research questions for this study include what is the motivation of tourists 
who came to visit Sakon Nakhon province, and what are the guidelines for management strategy of cultural tourism in Sakon Nakhon province?

\section{Objectives}

To study the motivation of tourists who visited Sakon Nakhon province

To study the guidelines of management strategy for cultural tourism in Sakon Nakhon province

\section{Methodology}

The location of this study is Sakon Nakhon province in the northeast of Thailand. To study the motivation of tourists who came to visit Sakon Nakhon province, we provided 800 questionnaires to 400 Thai tourists and 400 foreign tourists and we calculated a sample size using Yamane (1973). The questionnaire used the Linkert scale and offered five answers: strongly agree; agree; moderately agree; disagree; and strongly disagree. The closed questionnaire was interpreted by dividing the question scales into a 5-point scale as higher, high, moderate, low and lowest $(5.00-4.5,4.49-3.50,3.49-2.50,2.49-1.50$ and $1.49-1.00)$, and we analyzed this data using mean and standard deviation.

To study the management strategy of cultural tourism in Sakon Nakhon province, we used a focus group by inviting 20 people including the governor and all government agencies in Sakon Nakhon involved in tourism, tourist business agencies, and local residents to discuss the strategic management of tourism, and we analyzed this information using content and descriptive analysis.

\section{Literature Review}

Cultural tourism is a subset of tourism focused on a region's culture, specifically the lifestyle of the people, their history, their art and culture, architecture, and religion. One type of cultural tourism is living in culture and tradition areas (Mohammed, 2013; Rotich, 2012; Sigh, 2008, p. 314). Cultural tourism is the key to success of new tourism because it is flexible and includes green tourism (Richards, 2001). Cultural tourism is related to rural tourism. For example, culture and heritage often play an important role for economic growth in rural areas. In addition, cultural tourism related to rural development can utilize a region's natural and human resources, community and family relationships, and heritage and lifestyles, including a strong work ethic and quality of life (MacDonald \& Jolliffe, 2003). Seven factors relating to the management of tourism sustainability include: 1) natural resource protection; 2) traffic jams; 3) tax policies; 4) cost of travel; 5) labor, 6) waste management; and 7) crime (Sakolnakorn \& Naipinit, 2011).

In addition, infrastructure and transportation includes facilities for tourists such as electricity, water supply, Internet access, water, and accommodations (Naipinit et al., 2013a). Infrastructure and promotion related to tourism needs more attention from local government (Reihanian, Mahmood, Kahrom \& Wan Hin, 2012). In a study by Ahmad (2013) about tourism in Kampong Ayer, Brunei Darussalam, he found several factors related to tourism such as pollution from the indiscriminate disposal of waste, fire hazards, crime, loss of authenticity, lack of information, and lack of facilities and tourist services. In Kampong Ayer, several factors can challenge progress as a tourist destination.

Factors related to increasing cultural tourism include easy-to-follow routes, sufficient restrooms, clear directional signs, and reasonable prices (Sakolnakorn, Naipinit \& Kroeksakul, 2013). To maintain cultural tourism, older residents should teach local youth about local culture, encourage the museum to be the center of local cultural learning, and encourage community enterprises to produce goods and products related to tourism (Naipinit, et. al., 2013b). In addition, cultural tourism, agrotourism, and ecotourism are related to the livelihoods of the local residents (Kantawateera et. al, 2013).

Government policy is one factor related to tourism management. Policy-makers need to understand the nature of local tourism and the role of participation in policy-making (Stevenson, Airey \& Miller, 2008). Guidelines to develop cultural-related tourism include creating cultural value by printing local cultural pictures or pictures of tourist locations on souvenir products and building a souvenir shop downtown to promote tourism. The safety of visitors must be assured, and signs should be provided with directions to tourist attractions, bus routes, a phone number for a taxi service, and public transportation to various tourist attractions. Central and local governments should present and promote culture, and the night tourism landscape should be developed. However, at the same time, every development should also seek to be aware of environmental and social sustainability (Kantawateera, Naipinit, Sakolnakorn, \& Kroeksakul, 2014). As the literature review above shows, researchers can draw a conceptual framework as shown in Figure 1. 


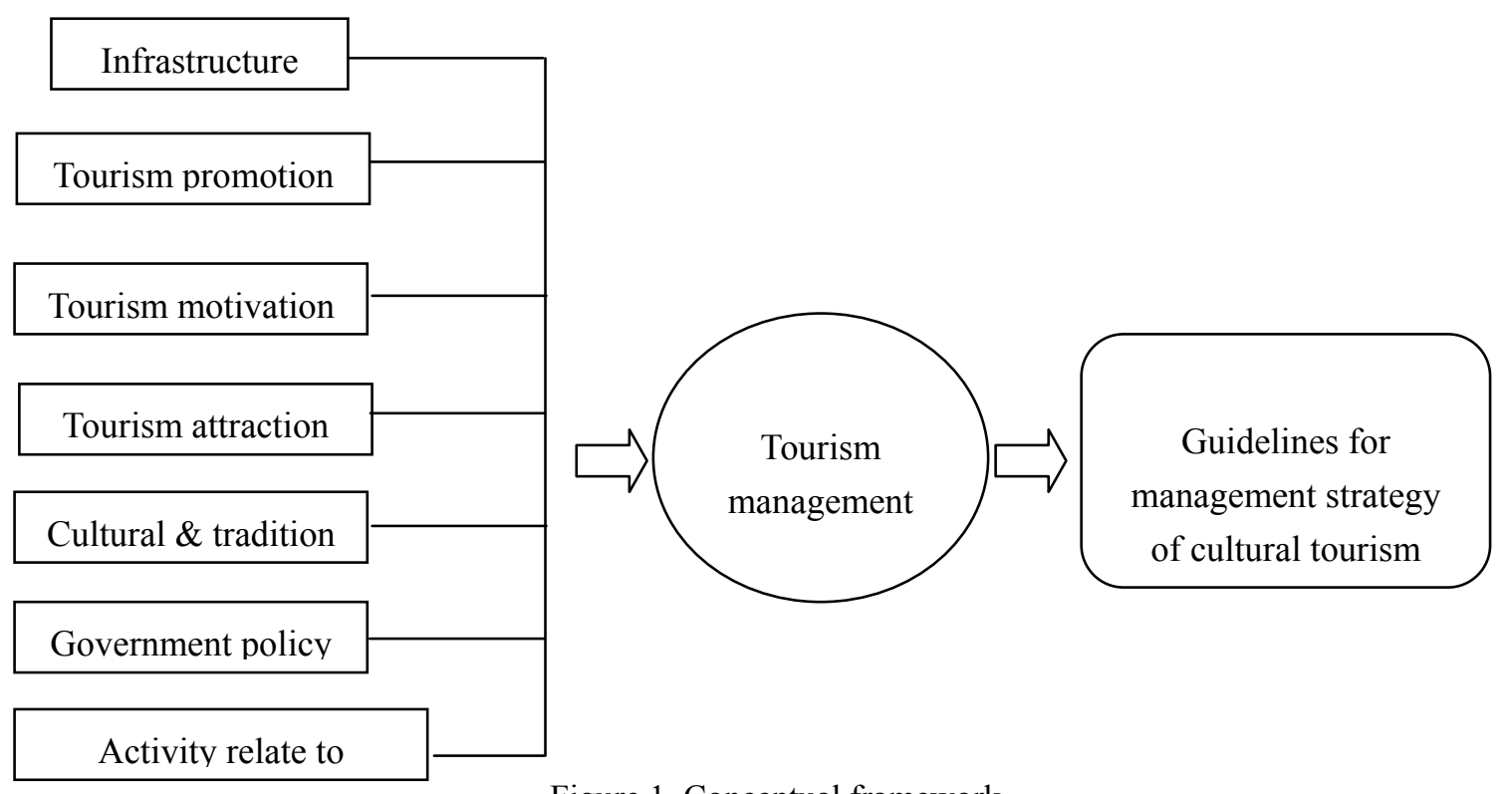

Figure 1. Conceptual framework

\section{Results}

From the study, we found that 27.5 percent of Thai tourists knew about tourist places in Sakon Nakhon by searching the Internet and website, 17.8 percent knew from a magazine, 26.8 percent of foreign tourists knew about Sakon Nakhon by searching the Internet and website, 17.3 percent received information from government agencies, and 16.5 percent from magazines. In addition, most of Thais and foreigner tourists came to travel at cultural tourism places more than 30 percent, ecotourism and natural sightseeing approximately 23 percent, and then the motivation of tourist came to visited Sakon Nakhon province as show on table 1.

Table 1. The motivation of tourists coming to visit Sakon Nakhon province

\begin{tabular}{|c|c|c|c|}
\hline \multirow{2}{*}{ The motivation of tourists coming to visit Sakon Nakhon province } & \multicolumn{3}{|c|}{ level } \\
\hline & $\bar{x}$ & S.D. & Level \\
\hline \multicolumn{4}{|l|}{ Cultural identity value } \\
\hline 1) Has many cultural tourism destinations showing local identity & 4.45 & 0.70 & High \\
\hline 2) Has many historic tourism locations & 4.60 & 0.65 & Higher \\
\hline 3) Has several local cultures and traditions & 4.60 & 0.65 & Higher \\
\hline $\begin{array}{l}\text { 4) Has many souvenirs demonstrating culture, tradition, and the identity of Sakon } \\
\text { Nakhon }\end{array}$ & 4.52 & 0.72 & Higher \\
\hline 5) Promotes local wisdom as provincial identity & 4.61 & 0.67 & Higher \\
\hline \multicolumn{4}{|l|}{ Aesthetic value } \\
\hline 1) Good environment for cultural tourism places & 4.49 & 0.80 & High \\
\hline 2) Good examples of architecture such as local houses and buildings & 4.52 & 0.66 & Higher \\
\hline 3) Has several local Thai dialects in several melodious accents & 4.46 & 0.68 & High \\
\hline 4) Local people are friendly and will help and support tourists & 4.39 & 0.68 & High \\
\hline \multicolumn{4}{|l|}{ Historical value } \\
\hline 1) Sakon Nakhon has ancient and historic tourist locations & 4.25 & 0.89 & High \\
\hline 2) Sakon Nakhon has many ethnic peoples and is interesting to visit and study & 4.22 & 0.88 & High \\
\hline 3) Ancient and historic locations related to culture and tradition & 4.31 & 0.87 & High \\
\hline $\begin{array}{l}\text { 4) Sakon Nakhon provincials have information and can promote ancient, historic, } \\
\text { cultural and tradition tourism }\end{array}$ & 4.44 & 0.75 & High \\
\hline
\end{tabular}


The motivation of tourists coming to visit Sakon Nakhon province

level

$\bar{x}$

Level

Creative economy value

1) Sakon Nakhon has many tourist programs and tourists have alternative choices for travel

2) Has local identity in the tourist program

3) Has many local handicrafts, handmade goods, and products relating to local identity, ancient history, and traditional culture

4) Has many choices of local food and beverages

Utility value

1) Has several tourism activities and attractive places

2) The tourism activities are motivated to attract tourists

3) Local products present the local identity

4) Creating local products and souvenirs related to local culture, tradition, history, and local ethnic identity

\section{Education value}

1) Has food and beverage practice for tourists interested in trying the local food

2) Sakon Nakhon provincials have supported the local arts and local culture by setting up activities and events

$4.59 \quad 0.70 \quad$ Higher

3) Learning and knowledge transfer about local culture, traditions, and handicraft of the local people

\section{$4.53 \quad 0.67 \quad$ Higher}

4) Have knowledge of Thai medicine, massage, and herb products

$\begin{array}{lll}4.36 & 0.72 \quad \text { High }\end{array}$

From Table 1, we found that all stakeholders including government agencies, businesses, local residents and communities understand how important tourism activities are because they realize income from tourism. Furthermore, transfer knowledge from the current generation to the next generation is important to preserve local wisdom, maintain traditions and culture, and also can maintain the old style of handicraft production. In addition, the results of the guidelines of management strategy for cultural tourism in Sakon Nakhon province is in Table 2.

Table 2. Guidelines for strategy management of cultural tourism

\begin{tabular}{ll}
\hline \multicolumn{1}{c}{ Strategy } & Management \\
\hline Set up tourist motivation based on a creative tourism & 1) Set up the core values of local cultural identity \\
economy promoting sustainability & 2) Restore the landscape and environment of tourist \\
places & 3) Transfer knowledge and provide information about \\
the story of historical places & 4) Make food and beverages that refer to the identity \\
of local residents and of the region \\
5) Use ethnic identity to promote and to be a selling \\
point of cultural tourism \\
6) Transfer knowledge and education to support \\
cultural tourism \\
1) Set up a new tourism information center and tourist \\
information kiosk in many tourist destinations \\
2) Set up new tourism activities related to cultural and \\
traditional tourism
\end{tabular}


Strategy

\begin{tabular}{|c|c|}
\hline Strategy & Management \\
\hline & $\begin{array}{l}\text { 3) Have festivals and create performances about local } \\
\text { culture in tourist locations } \\
\text { 4) Create more souvenirs related to cultural, historical } \\
\text { and traditional events, and build more souvenir } \\
\text { shops } \\
\text { 5) Marketing promotion such as organizing more } \\
\text { festivals and events relating to tourism }\end{array}$ \\
\hline Cultural tourism performance & $\begin{array}{l}\text { 1) Use local identity as a source of information to } \\
\text { travelers and set up information channel to promote } \\
\text { them } \\
\text { 2) Road construction and renovate routes to tourist } \\
\text { places; public transportation is also important } \\
\text { 3) Develop the infrastructure such as Internet wireless } \\
\text { access tourist locations, and restrooms } \\
\text { 4) Set up many tourism programs, increase channels of } \\
\text { tourism information, and use government agencies } \\
\text { as marketing channels } \\
\text { 5) Set up night tourism activities related to local } \\
\text { culture, such as stage shows }\end{array}$ \\
\hline Paradise of creative tourism sustainability & $\begin{array}{l}\text { 1) Set up symbolic interpretations of cultural tourism } \\
\text { and promote using all information channels such as } \\
\text { magazines, radio, TV, and billboards } \\
\text { 2) Give greater understanding of sustainable tourism } \\
\text { to local residents; for example, show how tourism } \\
\text { relates to economics, how criminal activity relates } \\
\text { to tourism, tourism and the employment issue, and } \\
\text { environment and tourism }\end{array}$ \\
\hline
\end{tabular}

From Table 2, we present strategic management of cultural tourism in Sakon Nakhon province. This strategic management will be a guideline for all participants and stakeholders to create cultural tourism sustainability. In addition, Sakon Nakhon cultural center and the museum of Archan Man Purithattha Thera is required to renovate and receive maintenance support from the local government budget, including establishing a small flower park. In addition, creating activities related to tourism is also important; for example, a night market selling local handicrafts or adventure activities such as renovating the walking route at Phu Phan National Park. Other possibilities include creating more water activities at Nong Han Lake, such as fishing, water skiing and renovate the park surrounding Nong Han Lake. Meetings, Incentives, Conventions and Exhibitions (MICE business) can create activities that can relate to cultural tourism. Local residents should be involved as part of cultural tourism and receive the knowledge of traditions and folklore which contribute to tourists' authentic experiences without endangering natural resources.

\section{Conclusion}

Sakon Nakhon province has many attractive tourism places. These include historical attractions such as Phra That Phu Pek, an ancient Khmer ruin built from sandstone. There are handicraft products such as Ban Charn Arts and Crafts Center, a producing and training center for weaving silk, local textiles, and wood carving. There are ethnic villages such as the Phu Thai Ethnic group at Ban None Hom. They immigrated from the left side of the Mekong River (once the Lao People's Democratic Republic/Lao PDR) to settle here more than a century ago. In addition, there are cultural festivals such as a wax castle procession and the traditional boat race held during the 
end of Buddhist Lent. Maintaining sustainable tourism in Sakon Nakhon province depends on the collaboration of all stakeholders cleaning the city, establishing a good environment, creating a city without crime, with reliable infrastructure such as roads, public transportation, and enough toilets In addition, tourism development should be based on local culture, traditions, and all activities and festivals should refer to the regional identity. The various ethnic communities is also selling point for tourism, so the ethnic community should to maintain the good tradition, culture and old style of handicraft production for staying alive under globalization culture. All these aspects will bring many travelers to visit and spend money at ethnic villages.

\section{Policy Recommendation}

7.1 Universities and colleges in Sakon Nakhon province should revise the tourism curriculum to be more suitable toward local culture and tradition, and should to collaborate with tourism business agencies.

7.2 Government agencies should show more concern, revise tourism policy, and invite all stakeholders to participate in how to develop tourism policy.

7.3 Government agencies should to set up a Creative Tourism Award for the community that can best use their identity, culture, and tradition to relate to tourism.

\section{References}

Ahmad, A. (2013). The constraints of tourism development for a cultural heritage destination: The case of Kampong Ayer (Water Village) in Brunei Darussalam. Tourism Management Perspectives, 8(October), 106-113. http://dx.doi.org/10.1016/j.tmp.2013.09.002

Kantawateera, K., Naipinit, A., Sakolnakorn, T. P. N., Churngchow, C., \& Kroeksakul, P. (2013). A SWOT Analysis of Tourism Development in Khon Kaen, Thailand. Asian Social Science, 9(17), 226-231. http://dx.doi.org/ass.v9n17p226

Kantawateera, K., Naipinit, A., Sakolnakorn, T. P. N., \& Kroeksakul, P. (2014). The satisfaction of tourists and policy guidelines for tourismd in Khon Kaen, Thailand. Asian Social Science, 10(6), 53-60. http://dx.doi.org/10.5539/ass.v10n6p53

MacDonald, R., \& Jolliffe, L. (2003). Cultural rural tourism Evidence from Canada. Annals of Tourism Research, 30(2), 307-322. http://dx.doi.org/10.1016/S0160-7383(02)00061-0

McIntosh, R. W., \& Goeldner, C. (1994). Tourism: Principles, Practices, Philosophies. New Jersey: Wiley and Sons.

Mohammed, A. (2013). Cultural tourism. Retrieved April 15, 2014, from http://madrastourist.wordpress.com /2013/03/28/cultural-tourism/

Naipinit, A., Maneenetr, T., Sakolnakorn, T. P. N., Churngchow, C., \& Kroeksakul, P. (2013a). SWOT Analysis of Religious Tourism in the Roi Kaen Sarn Sin Cluster of Northeastern Thailand. Asian Social Science, 9(12), 262-269. http://dx.doi.org/ass.v9n13p262

Naipinit, A., Maneenetr, T., Sakolnakorn, T. P. N., Churngchow, C., \& Kroeksakul, P. (2013b). Local community participation in the conserve candle festival, a case study of Ubon Ratchathani province, Thailand. Asian Social Science, 9(13), 282-288. http://dx.doi.org/ass.v9n13p282

National Statistical Office of Thailand. (2011). Situation to domestic traveler, Sakon Nakhon province: 2009-2011. Retrieved April 15, 2014, from http://service.nso.go.th/nso/web/statseries/tables/44700_ Sakon.../16.5.xls

Reihanian, A., Mahmood, N. Z., Kahrom, E., \& Wan Hin, T. (2012). Sustainable tourism development strategy by SWOT analysis: Boujagh National Park, Iran. Tourism Management Perspectives, 4, 223-228. http://dx.doi.org/10.1016/j.tmp.2012.08.005

Richards, G. (2001). The Development of Cultural Tourism in Europe. In G. Richards (Ed.), Cultural Attractions and European Tourism. Wallingford: CABI.

Rotich, D. (2012). An analysis of the challenges facing cultural tourism development in Kenya. Research on Humanities and Social Sciences, 2(10), 214-221.

Sakolnakorn, T. P. N., Naipinit, A. \& Kroeksakul, P. (2013). Sustainable tourism development and management in the Phuketprovince, Thailand. Asian Social Science, 9(7), 75-84. http://dx.doi.org/10.5539/ass.v9n7p75

Sakolnakorn, T. P. N., \& Naipinit, A. (2011). The problem and threat in the management of tourism sustainability in Phuket. International Journal of Management \& Information Systems, 15(2), 111-115. 
Sakon Nakhon Provincial. (2013). Briefing of Sakon Nakhon province. Retrieved April 15, 2014, from www.sakonnakhon.go.th/dataprovince/sakon.doc

Sigh, L. K. (2008). Fundamental of tourism and travel. Delhi: ISHA Books.

Stevenson, N., Airey, D., \& Miller, G. (2008). Tourism policy making: The policymakers' perspectives. Annals of Tourism Research, 35(3), 732-750. http://dx.doi.org/10.1016/j.annals.2008.05.002

Wei, W. (2012). Research on the cross-cultural marketing strategy of China's tourism enterprises. Procedia Environmental Sciences, 12, 1110-1115. http://dx.doi.org/10.1016/j.proenv.2012.01.395

Wikitravel. (2014). Sakon Nakhon. Retrieved April 15, 2014, from http://wikitravel.org/en/Sakon_Nakhon

Yamane, T. (1973). Statistics: An Introductory Analysis (3rd ed.). New York: Harper and Row Publication.

\section{Copyrights}

Copyright for this article is retained by the author(s), with first publication rights granted to the journal.

This is an open-access article distributed under the terms and conditions of the Creative Commons Attribution license (http://creativecommons.org/licenses/by/3.0/). 